A Journal of Agricultural Science Publisbed by

the California Agricultural Experiment Station

\title{
THE LEAF BLIGHT DISEASE OF ALMOND AND ITS CONTROL
}

JOSEPH M. OGAWA, E. E. WILSON, and HARLEY ENGLISH 
Leaf blight occurs in the Sacramento Valley and in the northern part of the San Joaquin Valley on most varieties of almonds. This disease has not been reported from any other part of the world. On highly susceptible varieties (Drake, Ne Plus Ultra, and Peerless) 15 to 20 per cent of the leaves may be destroyed during the growing season. An immediate reduction in productivity, however, results from the loss of leaf and flower buds, which are killed by the extension of the causal fungus (Hendersonia rubi Sacc.) from the base of the leaf petiole into the supporting twig. Leaf blight is identified by the sudden wilting and dying of leares throughout the summer. Although a few affected leaves fall, most do not. Fragments of the petioles remain on the tree and produce conidia the following winter and spring. The conidia of the fungus are shaped much like conidia of Coryneum beijerinckii Oud. (cause of the Coryneum blight of almond) but are much smaller.

Control may be obtained by spraying trees with either an eradicative or a protective fungicide. The eradicative fungicide, sodium pentachlorophenoxide, applied in spring just before the buds begin to open is effective against both leaf blight and the brown-rot blossom blight disease caused by Sclerotinia laxa. $\mathrm{N}$-phenylmercuriethylenediamine is also an effective eradicative fungicide against the leaf blight fungus. Protective fungicides (captan, ziram, and dichlone) applied at the petalfall stage of bloom, as recommended for the control of Coryneum blight, also reduce infection by the leaf blight fungus. 


\title{
H I L G A R D I A
}

A Journal of Agricultural Science Published by

the California Agricultural Experiment Station

\section{THE LEAF BLIGHT DISEASE OF ALMOND AND ITS CONTROL ${ }^{1}$}

\author{
JOSEPH M. OGAWA, ${ }^{2}$ E. E. WILSON, ${ }^{3}$ and HARLEY ENGLISH
}

\section{INTRODUCTION}

A PREviously undescribed disease of almond, which we have named "leaf blight," was found in an almond orchard near Chico, Butte County, in 1950. It has since appeared throughout the Sacramento Valley and the northern part of the San Joaquin Valley where about 84 per cent of the state's 102,470 acres of almonds are located. Although the leaf blight disease was not recognized before 1950, a fungus morphologically similar to the organism described in this article was isolated by one of the authors as early as 1930 . In view of this information and the present wide distribution of the leaf blight disease in California, it is possible that the disease has been present to some extent in the state for many years.

\section{LEAF BLIGHT DISEASE}

Almond leaf blight is characterized by the dying of leaves throughout the summer. One or more leaves of the shoots or spurs first wither, turn brown, and dry up (fig. 1A). This is followed by the death of other leaves. Although some affected leaves fall, most do not, and petioles of the latter can be found on the tree the following spring (fig. 1B). The tissues at the base of such persisting petioles will then have died well below the level at which the abscission layer forms; sometimes a dark-brown, slightly depressed superficial lesion is formed on the twig around the base of the petiole. The necrotic areas are slightly depressed and extend only superficially into the bark.

In late fall or early winter, dormant buds in the axils of affected leaves are killed by an extension of the lesion from the base of the petiole. A less noticeable symptom of the disease is the death of flowers in spring. Like dormant buds, flowers are killed by an extension of the lesion from the base of the petiole.

The causal fungus is not visible on the affected leaves in summer, but in winter a zone at the lower end of the persisting petiole remains tan-colored

${ }^{1}$ Submitted for publication February 25, 1958.

${ }^{2}$ Lecturer in Plant Pathology and Assistant Plant Pathologist, University of California at Davis.

${ }^{3}$ Professor of Plant Pathology and Plant Pathologist, University of California at Davis.

${ }^{4}$ Professor of Plant Pathology and Plant Pathologist, University of California at Davis. 


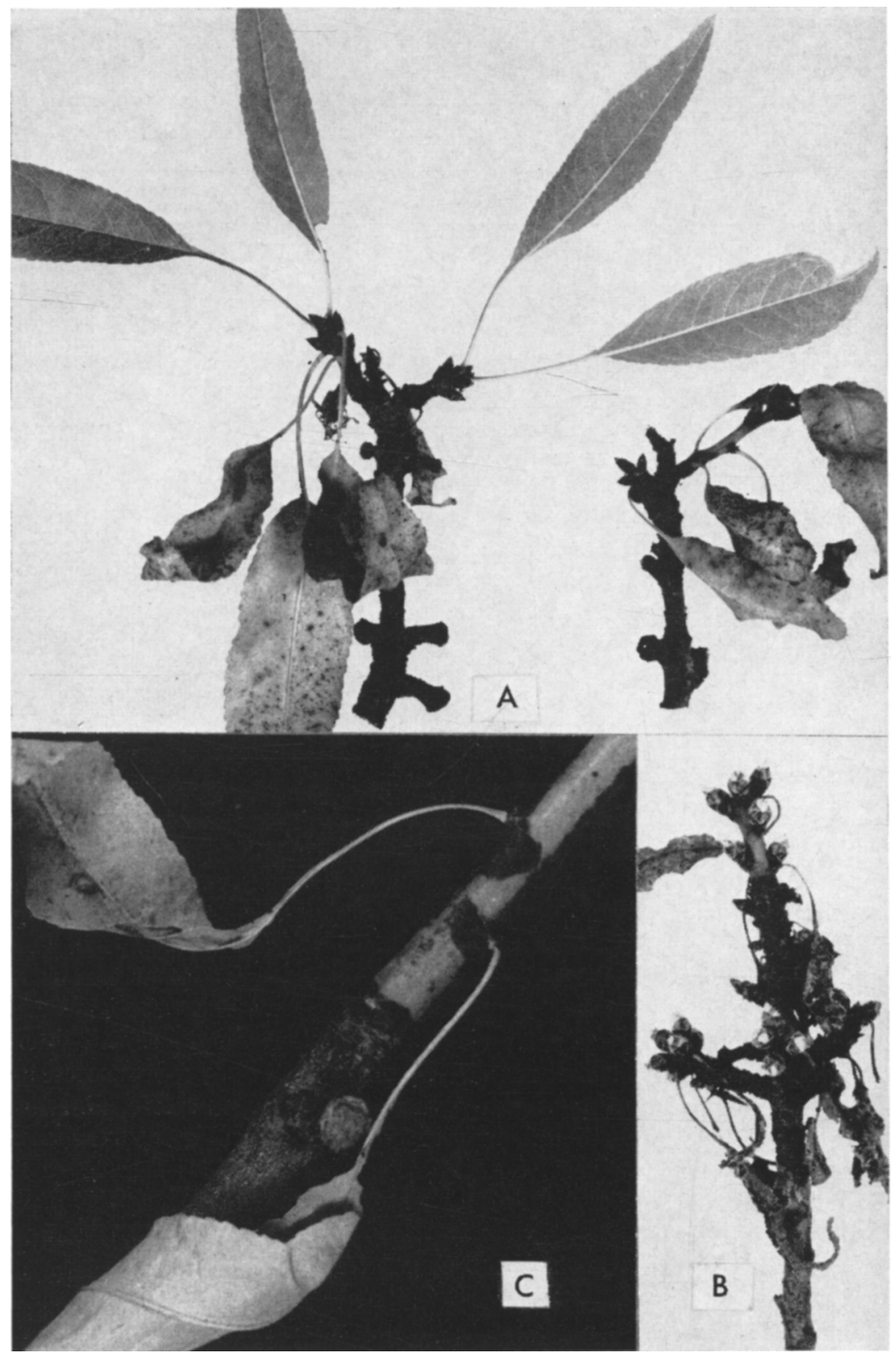

Figure 1.-Symptoms of the leaf blight disease. $A$, Leaves which have withered and died recently. $B$, Remnants of leaves killed by the disease in the summer are still present on the twig the following spring. $C$, Lesions produced by the leaf blight fungus on a shoot at the base of blighted leaves. 
while the rest of the petiole turns dark brown. Scattered over the surface of the tan zone are dark fruiting structures of the causal fungus.

Although the number of leaves killed in any one year is seldom great enough to affect the productivity of the tree, successive losses of leaves for several years eventually will do so. On the other hand, an immediate reduction in productivity results from the killing of dormant buds and flowers. Nodes at which buds are killed will not thereafter produce either fruit or leaves.

Other stone-fruit trees, such as peaches and plums, growing adjacent to infected almond trees have not contracted leaf blight. While all almond varieties grown in the Sacramento Valley exhibit noticeable differences in susceptibility, none is immune to the disease. The Drake, Ne Plus Ultra, and Peerless are highly susceptible, whereas the Nonpareil, Texas (Mission), and IXL are moderately susceptible.

\section{FUNGI ISOLATED FROM BLIGHTED LEAVES}

Pieces from recently affected leaf blades, leaf petioles, and flower parts were immersed for two minutes in a solution containing one part of a 5.25 per cent preparation of sodium hypochlorite to 10 parts of sterile water. The pieces were then planted on plates of potato-dextrose agar. Several fungi, almost all of which are known to be common saprophytes, were isolated from the blade and from the upper part of the petioles of affected leaves. On the other hand, the lower part of the petioles consistently yielded one fungus. In 1955, for example, this fungus was isolated from 75 per cent of the samples collected from 20 or more orchards in localities throughout the Sacramento Valley. The same fungus, hereafter termed the "leaf blight fungus," was readily obtained from newly blighted blossom parts. Moreover, the fungus fruiting structures which emerged from the remnants of affected petioles on the tree were found to be those of the leaf blight fungus.

On spurs on which all leaves had withered at one time, only 10 to 41 per cent of the petioles yielded the leaf blight fungus, while 20 to 36 per cent yielded Coryneum beijerinckii Oud. (Clasterosporium carpophilum (Eév.) Aderh.; Coryneum carpophilum (Lév.) Jauch). C. beijerinckii is known to blight entire clusters of spur leaves. On the other hand, the leaf blight fungus but not $C$. beijerinckii was obtained from the blighted petioles of leaves on spurs where only one or two leaves had died at one time.

\section{INOCULATIONS WITH THE LEAF BLIGHT FUNGUS}

Leaves of the Peerless and Ne Plus Ultra varieties of almond were inoculated with the leaf blight fungus. In the first tests, leaves on detached shoots were sprayed with a spore suspension of the fungus. For comparison, other detached shoots were sprayed with a suspension of Coryneum beijerinckii spores. The shoots were placed with their cut ends in water and enclosed in a moist chamber which was held at room temperature. Within about five days, $C$. beijerinckii produced numerous lesions on the leaf blades, while the leaf blight fungus did not. In one experiment, six leaves withered and died in a manner typical of leaf blight in the orchard, and the leaf blight fungus was isolated from the basal part of the petioles. 
In the next experiment dry spores of the leaf blight fungus were placed in the axils of the leaves of detached shoots enclosed in large test tube moist chambers. A week later most of the leaves so inoculated were withered and the fungus was recovered from the petioles at that time.

In the summer of 1956, inoculations were made on the trees in the field. Conidia were scraped from potato-dextrose agar cultures of the fungus and placed in the axils of five mature leaves on each of 10 shoots. The inoculated leaves were marked and the shoots were enclosed in plastic bags which contained moist cotton. Five of the bags were removed after 48 hours and five after 72 hours. No infection developed in three such experiments. In the summer of 1957, inoculation experiments were conducted as before, except that the conidia were taken from the petioles of infected almond leaves, the shoots were enclosed in wire cages covered with absorbent cotton and the lower ends of the cages were inserted in cans of water. Within five weeks, six inoculated leaves developed typical leaf blight symptoms and within the next four weeks seven more inoculated leaves developed symptoms. The leaf blight fungus was recovered from surface-sterilized petioles of these leaves. None of the uninoculated leaves on these shoots showed any of the symptoms of leaf blight.

\section{DESCRIPTION OF THE LEAF BLIGHT FUNGUS}

The fungus grew well on both potato-dextrose and oatmeal agars, where it produced abundant brown subsurface mycelium and dirty gray aerial mycelium. Conidia commonly were produced in separate groups scattered over the colony. At times the spore groups were arranged in concentric rings but, with time, they became so numerous as to form a more or less continuous layer. Vertical sections show fruiting structures to consist of a thin but compact layer of hyphae (prosenchyma) from which arise numerous slender hyaline conidiophores. The conidia, which will be described later, are borne on the ends of the conidiophores.

At times, well-defined pycnidium-like structures were found on the colonies (fig. 2D). These contained conidia identical in size, shape, and color with those produced on the fruiting structures just described. Both types of fruiting structures were produced by monoconidial isolates. In agar cultures the pycnidium-like structures were composed of a compact outer peridium of relatively thick-walled pseudoparenchyma and an inner layer of thin-walled sporogenous cells which lined the entire pycnidial cavity. Conidia but no ostioles have been found in specimens so far examined in culture.

A study was made of the fruiting habits of monoconidial isolates obtained from various orchards and localities. Differences in the color of mycelium and abundance of conidia were encountered but no consistent differences in the types of fruiting structure. Some colonies produced conidia on layers of prosenchyma at one time and similar conidia in pyenidia at another time.

On naturally infected petioles, conidia typical of those produced in culture were found in fruiting structures which varied greatly in size (115 to $165 \mu$ in diameter), shape, and structure. The more common-hereafter called the acervulus type-consisted of a convex basal layer of pseudoparenchyma 


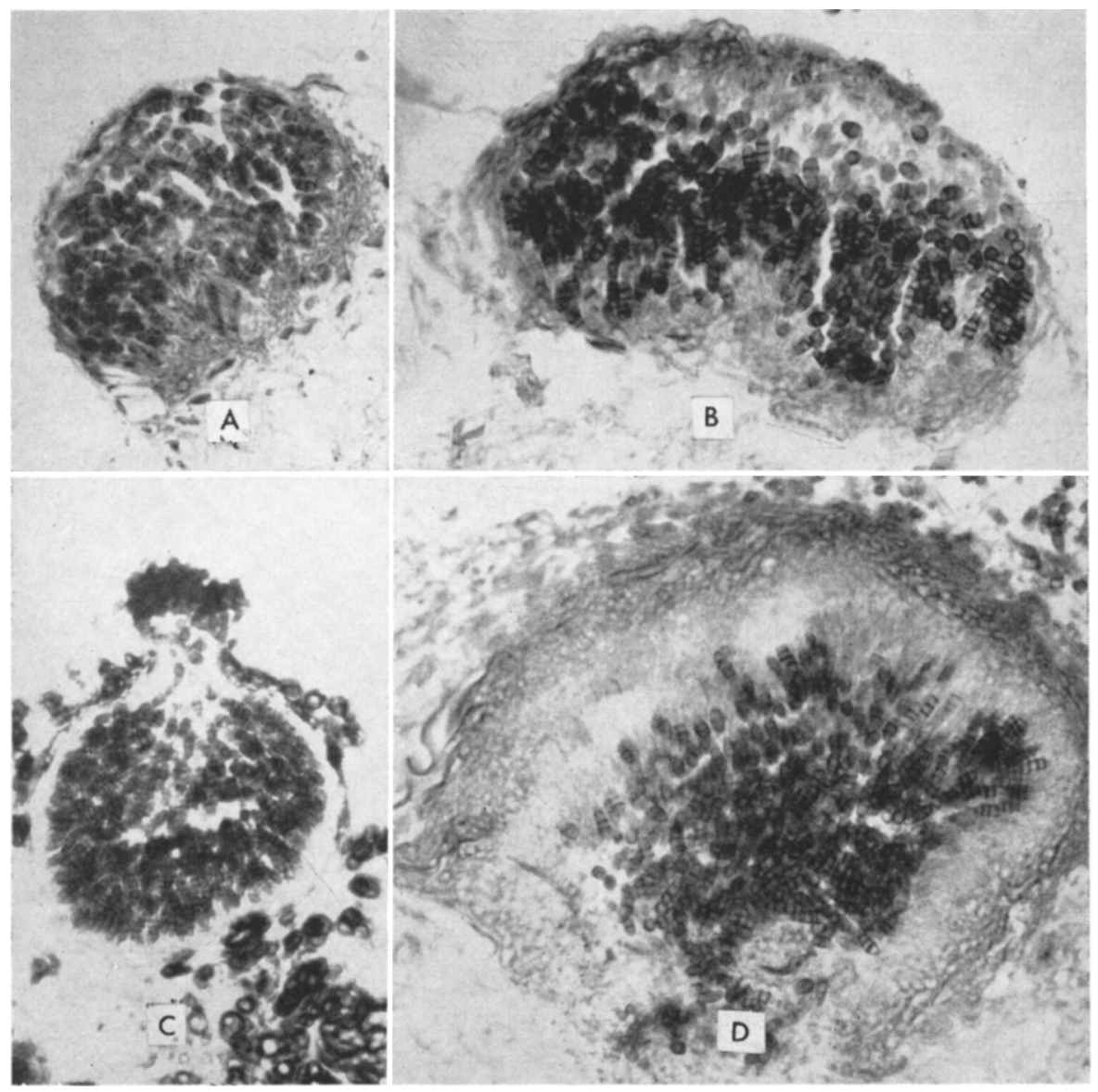

Figure 2.-Fruiting bodies produced by the leaf blight fungus on the host $(A-C)$ and in agar colonies $(D) . A$, An acervulus-type of structure in which only the cuticle and crushed epidermis of the host cover the conidial cavity $(\times 386) . B$, A fruiting body similar to $A$, except that the conidial cavity is covered by fungus tissue $(\times 376)$. Conidiophores arise from the upper and lower walls of the conidial cavity. Such a structure possesses no welldefined pseudoparenchymatous peridium or ostiole. $C$, A typical pycnidium with a welldefined peridium and ostiole $(\times 381)$. The conidia appear to be smaller than those in $A$ and $B$ because they are badly shrunken. $D$, A pycnidium-like structure without ostiole produced in agar by a monoconidial colony of the leaf blight fungus $(\times 360)$. The same colony also produced conidia on hyphal mats at the surface of the agar.

covered by the upraised host epidermis and cuticle. In some (fig. $2 \mathrm{~A}$ ), very little if any fungus tissue occurred beneath the upraised epidermis, in others (fig. 2B), loosely intertwined fungus tissue (prosenchyma) covered the entire conidial cavity, but in no case was the outer layer of the covering a compact pseudoparenchymatous peridium. Conidiophores were produced both from inner cells of this covering and from cells at the base. The covering usually broke away when the epidermis and cuticle ruptured. With many older fruiting bodies of this type the covering disappeared, leaving an open 
saucer-shaped structure. None of the structures of this type was found with an ostiole or with a peridial layer of closely packed pseudoparenchyma. Conidia were borne on long sinuous conidiophores (fig. 3 ).

The second type of fructification on blighted petioles was a true pycnidium (fig. 2C) with a peridium of relatively thick-walled pseudoparenchyma cells and an ostiole. The diameter of the pycnidium ranged from 95 to $115 \mu$. No conidiophores could be detected in these structures. Conidia produced in the pyenidia were indistinguishable in shape, size, and color from those produced in the fruiting structure of the acervulus type.
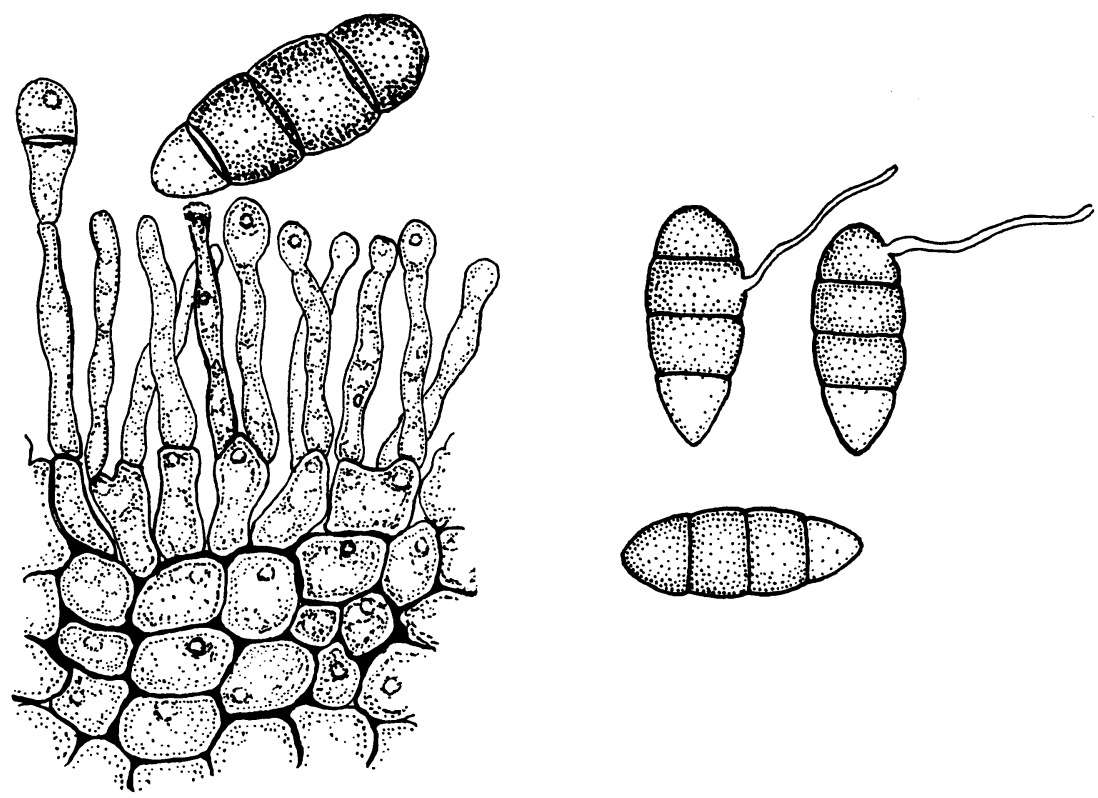

Figure 3.-Conidiophores and conidia of the leaf blight fungus.

Conidia from the host, like those from artificial media, were approximately elliptical in shape, with the base more pointed than the apex (fig. 3). At least 90 per cent of the conidia from the host were four-celled. They ranged from 11.9 to $17.7 \mu$ in length and 6.1 to $7.5 \mu$ in breadth (average 14.8 by $6.8 \mu$ ). Conidia from agar media, on the other hand, varied in size and in number of cells. Some possessed as many as six cells, others as few as three. The three-celled conidia averaged 13.1 by $5.2 \mu$, the four-celled conidia averaged 15.1 by $5.7 \mu$, and the six-celled conidia averaged 21.0 by $6.6 \mu$. In shape and color, however, they were identical to those from the host. The basal cell of the conidium was subhyaline, the other cells were usually light brown. The wall of the conidium was slightly constricted at the septa.

At first, both acervuli and pycnidia are immersed in the outer tissue of the leaf petiole, but later they become more or less erumpent. Pycnidia possibly originate a little more deeply in the host tissue than do acervuli. In one lot of material collected in winter, only fruiting bodies of the acervulus 
type were found, in another lot collected in spring pycnidia occurred almost as frequently as acervuli, while only acervuli occurred in two other lots collected in other years. We were unsuccessful in our attempts to separate the occasional pycnidium from the numerous acervuli which surround it in the host tissue. Consequently, we could not compare cultures from pycnidiumproduced conidia with those from acervulus-produced conidia. As noted earlier, however, cultural tests have not revealed any tendency for some isolates to produce only pycnidia and others only acervuli.

\section{CLASSIFICATION OF THE LEAF BLIGHT FUNGUS}

Because the leaf blight fungus produces both pycnidia and acervuli, it does not find a place in the present scheme of classification but must be assigned to either the order Sphaeropsidales or the order Melanconiales. If assigned to the former, the spore type would place the fungus in the Berkeley genus Hendersonia as emended by Saccardo ; if assigned to the latter, the spore type would place it either in the old genus Coryneum of Nees or in the newer genus Coryneopsis of Grove (1932), ${ }^{5}$ depending on the characteristics of conidia and conidiophores.

Certain species that have been placed in the genus Hendersonia are said to produce both acervuli and pycnidia. Archer (1926, p. 46-51) reports that Hendersonia rubi (West.) Sace. exhibits this characteristic as well as $H$. syringaecola Brun., $H$. piricola Sacc., and $H$. mali Thum. Because of this dimorphism, a number of species have been described both as Hendersonia and as Coryneum.

Archer's account of dimorphic fruiting bodies in Hendersonia rubi is particularly pertinent here and will be discussed in some detail. The fruiting bodies of this fungus are borne in the outermost cortex of the cane. Most of these are lens-shaped in vertical section. In its early stages the entire conidial chamber is lined with sporogenous tissue from which arise numerous conidiophores. There is less of this tissue on the upper than on the lower walls of the chamber. As the fruiting body reaches maturity, however, the upper wall is strongly arched, and finally ruptures in a "stellate or irregular manner," leaving only the basal layer of pseudoparenchyma. If seen at this stage, the structure would be taken for an acervulus and the fungus would be considered a member of the genus Coryneum. Frequently, however, pyenidia are formed on the same cane. The pycnidium tends to be globose and possesses a well-defined peridium. The spores are exactly alike in both types of fruiting bodies. They are four-celled, the upper three cells being brownish, the basal cell hyaline, like the conidiophore. According to Saccardo (1884, p. 424) the conidia of $H$. rubi are 12 to $18 \mu$ long and 5 to $6 \mu$ broad.

Zeller (1925), studying a cane blight of raspberries in Oregon, first believed the imperfect stage of the causal fungus to be Coryneum ruborum Oud. and, therefore, named the ascigerous stage, which he discovered, Ascospora ruborum (Oud.) Zeller. After reading Archer's paper, however, Zeller published a correction (1927) in which he said the imperfect stage of his fungus was Hendersonia rubi West. and the ascigerous stage Ascospora

\footnotetext{
"See "Literature Cited" for citations referred to in the text by author and date.
} 
rubi (West.) Zeller. Acervuli ranged from 120 to $135 \mu$ in diameter, the conidiophores were slender, hyaline, and 18 to $32 \mu$ long, and the conidia were ellipsoid, triseptate, more obtuse at the apex than at the base, fuligenous, 11 to $18 \mu$ long, and 6 to $7 \mu$ broad.

Dr. A. N. Steward, Curator of the Herbarium, Department of Botany, Oregon State College, kindly furnished us with specimens of diseased raspberry canes which Zeller collected between 1924 and 1926. One lot, labeled Coryneum ruborum, bore only acervuli of the fungus, the other, labeled Hendersonia rubi, bore both acervuli and pycnidia. Conidia from the two lots were similar in all respects. Except for a slightly deeper color, they closely resembled the conidia of the almond leaf blight fungus. Shrinkage from desiccation in storage might well have caused the spores in Zeller's collections to become darker.

Described species of Coryneum with conidia resembling those of the leaf blight fungus are C. microstictum Berk. and Br., C. foliicolum Fckl., and C. ruborum Oud. Kidd and Beaumont (1923-24) believe that $C$. foliicolum does not differ from $C$. microstictum. Archer (1926) considers $C$. ruborum synonymous with Hendersonia rubi and indicates that both $C$. microstictum and $C$. foliicolum might well be considered so. $C$. microstictum has been described on species of the genera Rosa, Rubus, Kerria, Crataegus, Arbutus, and Vitis (Saccardo, 1884, p. 775), and C. microstictum var. mali has been reported on a species of Malus. According to Saccardo (1884, p. 775), C. microstictum produces subpyriform to oblong conidia which are 15 to $17 \mu$ long by 5 to $6.5 \mu$ broad and quadriloculate, the basal locule being subhyaline.

More recently Grove (1932) erected a new genus, Coryneopsis, to which he transferred Hendersonia rubi West. and Coryneum microstictum Berk. and $\mathrm{Br}$. Although he retained the species names, he listed Hendersonia rubi as a synonym of both Coryneopsis rubi and Coryneopsis microsticta. The new genus, in the order Melanconiales, produces conidia resembling those of Hendersonia and Coryneum as to shape and septations but differing in that the lateral walls between the septa collapse inward when the conidium matures. Coryneopsis produces no peridium around the fruiting body or, at the most, a very thin one, while Hendersonia produces a well-defined peridium. Moreover, the conidia of Coryneopsis develop on long, filiform, persistent conidiophores, while in Hendersonia the conidiophores are short.

The almond leaf blight fungus produces abundant long, slender conidiophores which persist even in old acervuli. Except in fixed and stained material, however, the walls of its conidia were not found to collapse inward. At the present time, therefore, we do not believe that our isolate should be placed in the genus Coryneopsis, but because it produces pycnidium-like structures in culture and because there are indications it does so on the host, we prefer to identify it as a Hendersonia closely resembling the morphological species listed by Saccardo as $H$. rubi West., Sacc. However, since Saccardo appears to have described $H$. rubi as a species distinct from $H$. sarmentorum West (the name first employed for a species of Hendersonia found on grapes and brambles) the International Code of Botanical Nomenclature requires that Saccardo's name only be used as the authority for this combination (see also Grove, 1937, p. 83). Although Archer (1926) con- 
cluded that $H$. rubi and $H$. sarmentorum are synonymous, it is the opinion of the present authors that only further detailed study can definitely establish this point. On the basis of information presently available and in accordance with the International Code, it appears that the binomial which best applies to the almond leaf blight fungus is $H$. rubi Sacc.

\section{RELATION OF TEMPERATURE TO GERMINATION OF CONIDIA AND GROWTH OF MYCELIUM}

The leaf blight fungus was grown on oatmeal agar in tubes. Water, containing glass beads, was added to the tubes, and the tubes were shaken to release the conidia from the substrate. The conidia were freed of other material by repeated centrifugation and resuspension in sterile water, after which they were suspended in a solution containing 10 milligrams trisodium citrate and 1 gram sucrose per liter of water, dispensed in hänging-drop microscope slides, and incubated at $25^{\circ} \mathrm{C}$. Germination began within five hours and by far the greater number of conidia produced only one germ tube which arose most frequently from a central cell (fig. 3), but occasionally from the apical cell. No more than two of the cells germinated, even after 42 hours and after alternate wetting and drying.

Drops of the conidial suspensions were placed on the surface of water agar in Petri plates and incubated at various temperatures. After 24 hours the percentage of spore germination was low at $12^{\circ}, 15^{\circ}$, and $18^{\circ} \mathrm{C}$ but increased rapidly with successive increases in temperature from $18^{\circ}$ and $27^{\circ} \mathrm{C}$. The optimum appears to be between $24^{\circ}$ and $30^{\circ} \mathrm{C}$, while $33^{\circ} \mathrm{C}$ was relatively unfavorable to germination.

To determine the relation of temperature to mycelial growth, a single conidium was placed at the center of each of five Petri plates of 2 per cent potato-dextrose agar, and after incubation at various temperatures for 7 and 13 days, the diameters of the colonies were measured. The optimum temperature for mycelial growth as well as spore production was between $21^{\circ}$ and $24^{\circ} \mathrm{C}$ (fig. 4). Although the fungus grew rapidly at $27^{\circ} \mathrm{C}$, few conidia were produced.

\section{DEVELOPMENT OF THE DISEASE}

The almond leaf blight fungus survives from one year to the next in the petioles of the blighted leaves that remain on the trees and in the affected part of the shoot. Conidia produced on these petioles provide abundant inoculum for infection. They begin to appear in November and December and by spring are present in large numbers.

Judging from observations during the past three years, the leaf blight disease follows a consistent pattern of development. The first symptom to become apparent in the growing season is the withering of the unopened flowers shortly after they emerge in spring from the winter buds in the axils of blighted leaf petioles. In 1956 blossom blighting in the Peerless variety of almond was noticeable by mid-March.

The first symptom of conidial infection is the withering of the leaves, which appears sometime in June. Other leaves, as they are produced, may 
wither and die throughout the summer and well into autumn. Presumably, therefore, infection by conidia occurs repeatedly from midsummer to autumn.

Extension of the fungus from the base of the infected leaf petiole into the twig and thence into the base of the adjacent dormant buds, occurs some-

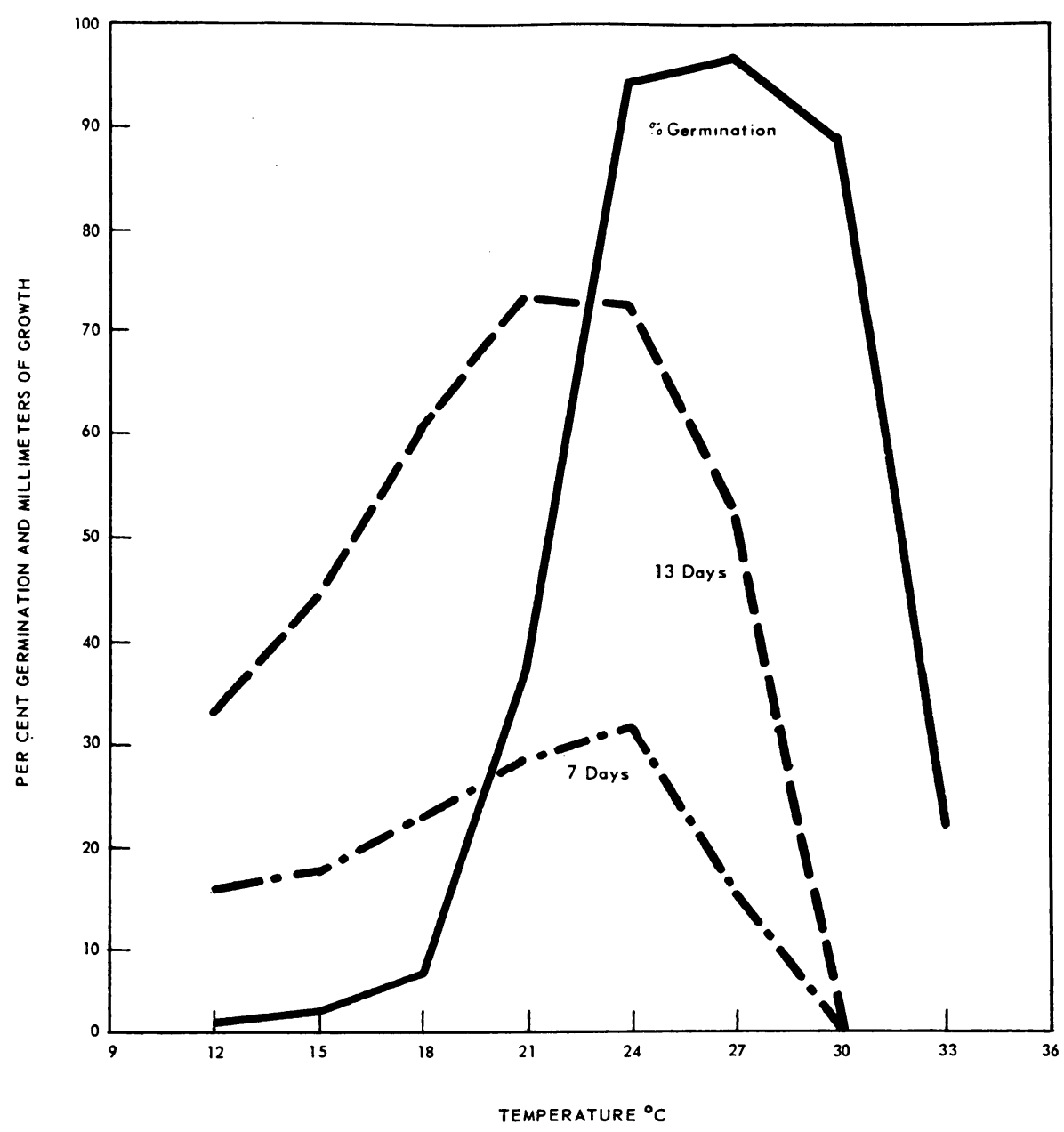

Figure 4.-Relation of temperature to germination of conidia (solid line) and to growth of mycelium (broken lines).

time during late summer and early autumn. Examinations in two Butte County orchards of the Ne Plus Ultra variety on November 2, 1955, showed that 31 and 81 per cent, respectively, of the buds adjacent to infected petioles were dead. On trees of the same variety in Sutter County, 25 per cent of the buds in the same position were dead by November 8 . Killing of the emerging flowers in spring apparently is a continuation of this type of mycelial invasion. 


\section{CONTROL BY FUNGICIDES}

Experiments to control almond leaf blight were conducted by two types of spraying: (1) protective spraying, in which fungicides were applied to the growing tree to protect the leaf petioles from conidial infection; and (2) eradicative spraying, in which fungicides were applied to the dormant tree in late winter to kill the conidia.

Protective Spraying. To obtain information on the protective value of different fungicidal materials and on the proper timing of the spray applications, blocks of trees were chosen in almond orchards throughout which the incidence of leaf blight had been uniformly high. Each material was applied to single trees situated in different parts of the block, each treatment was replicated six to eight times. At the end of the season the incidence of leaf blight was estimated in each tree by counting the blighted leaves on 20 branches of equal length, the branches being selected at random from the north, south, east, and west sides of the trees.

In 1955, six plots of almond trees were sprayed with each of the following preparations: Bordeaux mixture, 10-10-100 ; or 50 per cent captan (N-trichloromethylthio)-4-cyclohexene-1,2-dicarboximide), 2 pounds to 100 gallons of water; or 76 per cent ziram (zine dimethyldithiocarbamate), 2 pounds to 100 gallons of water. The sprays were applied at the following stages of tree growth: (1) bud swelling (Jan. 26), after buds had swelled appreciably but before the scales had separated; (2) popcorn (Feb. 22), after flowers had emerged from the buds but before petals began to unfold; (3) 40 to 60 per cent flowers open (March 1) ; (4) petal fall, after most petals had fallen from the flowers (March 7); (5) three weeks after petal fall (March 31); (6) five weeks after petal fall (April 15); (7) seven weeks after petal fall (April 30); and (8) nine weeks after petal fall (May 12). Plots sprayed at the bud swelling stage and five, seven, and nine weeks after petal fall received no other sprays. Plots sprayed at the popcorn and the 40 to 60 per cent blossom stages, received the same fungicide at the earlier stages.

Trees at bud-swelling and three, five, seven, and nine weeks after petal stage of bloom received single spray application at these stages of growth. Those sprayed at popcorn also received the same spray at bud swelling; those sprayed at 40 to 60 per cent bloom received also a popcorn and bud swelling application; and those sprayed at petal fall received the 40 to 60 per cent bloom, popcorn and bud-swelling sprays.

The results of this experiment (fig. 5) show that treatments at the budswelling stage and at the popcorn stage did not materially reduce the disease. This was not unexpected since little or no foliage was present on the trees when the sprays were applied and, consequently, the infection sites were not covered by the fungicide. Ordinarily, leaves begin to emerge during the blooming period, and many of the spur leaves and some of the leaves on shoots have unfolded by the end of the blossoming period. Applications made when 40 to 60 per cent of the blossoms were open reduced the disease to some extent, while those made at the petal-fall stage reduced the disease even more. Effective disease control also was obtained from spray applications made three weeks after petal fall, but the degree of control decreased 
progressively as the treatments were delayed five, seven, and nine weeks after petal fall. Apparently, therefore, maximum protection of the leaves is afforded by a spray applied at the end of the blossoming period (petal fall) or shortly thereafter.

Both ziram and captan gave satisfactory control when applied at the petal-fall stage. The small difference in favor of ziram at petal fall, three weeks after petal fall, and five weeks after petal-fall treatments, did not prove statistically significant. It is not possible to judge the effectiveness of

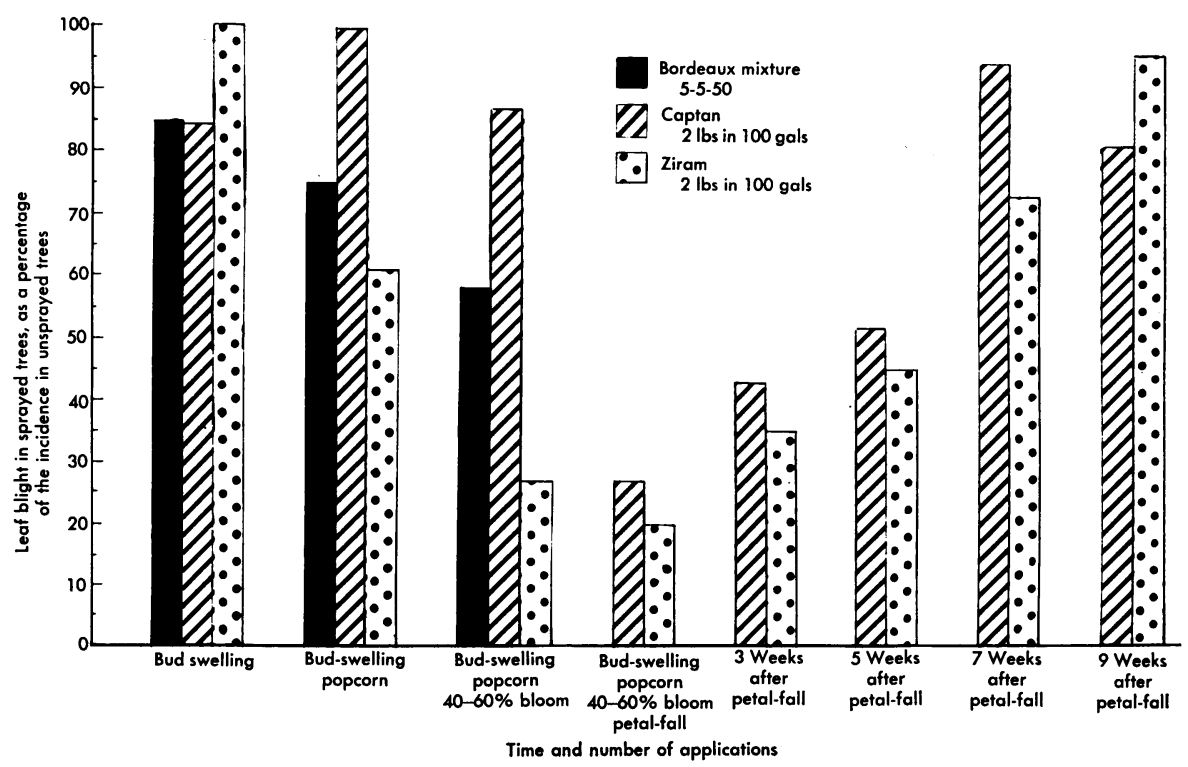

Figure 5.-Prevention of the leaf blight disease with protective fungicides in 1955. Materials were applied at different stages of host development.

Bordeaux mixture from the data in figure 5 , because a Bordeaux treatment was not given later than the 40 to 60 per cent bloom period, a time when not many leaves were present. Because of the danger of injury to foliage, Bordeaux mixture was not applied after leaves emerged.

In 1956, maneb, zineb, ziram, and dichlone were compared in one orchard and captan, zineb, and ziram in another. Two applications were made; the first at the popcorn stage, primarily for control of the shot-hole (C. beijerinckii) and brown rot (Sclerotinia laxa Aderh. and Ruhl.) diseases, and the second at the petal-fall stage, for the control of both leaf blight and shot-hole. Captan, dichlone, and ziram significantly reduced the incidence of leaf blight (table 1), but maneb and zineb reduced the disease little if any.

Eradicative Spraying. Since the leaf blight fungus survives in the tree, where in winter it produces conidia, it might prove vulnerable to eradicative fungicides. If conidia are responsible for all infection, their destruction should effect a material reduction in the disease, especially since conidia do not develop on newly infected leaves during the growing season. Eradicative materials, such as sodium pentachlorophenoxide and other phenolic 
compounds, have been used effectively and safely against three fungi (Sclerotinia laxa, Aderh. and Ruhl., Coryneum beijerinckii Oud., and Cladosporium sp.) which produce disease in almonds (W:ilson, 1943; Wilson and Ogawa, 1956). It was decided, therefore, to test the effectiveness of some of these materials against the leaf blight fungus. Accordingly, trees of the Drake variety of almond were sprayed on January 30, 1956, at which time the buds were swollen appreciably but the inner bud seales had not separated. The spray preparations compared were proprietary formulations of sodium pentachlorophenoxide (SPP), N-phenylmercuriethylenediamine (PMED),

TABLE 1

EFFECT OF PROTECTIVE FUNGICIDES ON THE CONTROL OF ALMOND LEAF BLIGHT DISEASE, 1956

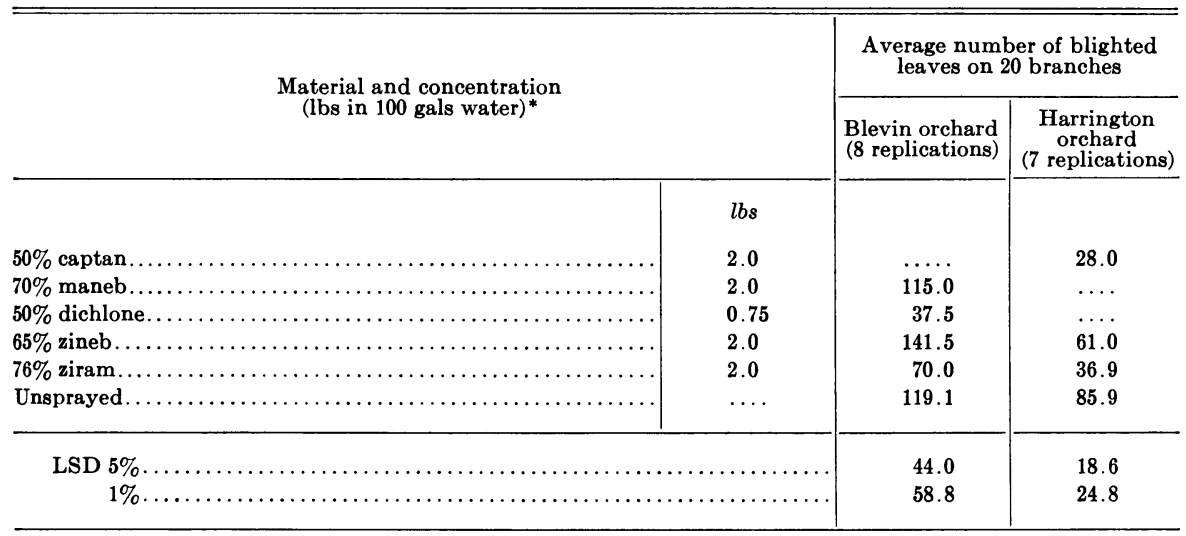

* Treatments given at popcorn and petal-fall stages of host development. The popcorn treatment was primarily for the control of Coryneum blight and brown-rot blossom blight.

dinitro-o-secondary amylphenol (DNAP), 2-secondary-butyl-4, 6-dinitrophenol (DNB), and a 1-4 mixture of DNAP and DNBP. ${ }^{6}$ On September 4, the incidence of leaf blight in the sprayed plots was estimated as described earlier.

In the meantime the effect of the five materials on the conidial inoculum was assessed on February 20 and April 30 as follows: Ten overwintered infected petioles which bore the fruiting structures of the fungus were collected at random from each treated plot. These were carefully macerated in a small amount of water to release the conidia. The suspension was centrifuged at a speed sufficient to separate the debris from the conidia. The conidia were suspended in redistilled water, and the suspension was centrifuged at a speed sufficient to throw down the spores. This process was repeated three times, after which the conidia were suspended in a solution containing 10 milligrams trisodium citrate and 1 gram sucrose per liter. Drops of this suspension were placed in the depression of hanging-drop microscope slides, and the slides were placed on racks in moist chambers

\footnotetext{
${ }^{6}$ Proprietary names of these materials were respectively: Dow Dormant Fungicide, Coromere, and formulations of Sinox General, Dow General, and Contax.
} 
kept at $21^{\circ} \mathrm{C}$. After 24 hours the per cent of conidia germinating was determined (table 2).

The spore germination tests showed that SPP and PMED had drastically reduced the number of viable conidia in the tree. Spraying with these two materials was followed by highly significant ( 86 to 87 per cent) decreases in the amount of new infection in the sprayed trees. On the other hand, DNAP apparently was ineffective against the conidial inoculum and, as might be expected, reduced leaf blight very little in the orchard. Although the viability of conidia in trees sprayed with DNBP and the DNBP-DNAP

TABLE 2

EFFECT OF ERADICATIVE FUNGICIDES ON THE CONIDIA OF THE ALMOND LEAF BLIGHT FUNGUS AND ON CONTROL OF THE LEAF BLIGHT DISEASE, 1956

\begin{tabular}{|c|c|c|c|c|}
\hline \multirow{2}{*}{\multicolumn{2}{|c|}{$\begin{array}{l}\text { Material and concentration } \\
\text { (amount in } 100 \text { gals water) }\end{array}$}} & \multicolumn{2}{|c|}{$\begin{array}{l}\text { Per cent of conidia } \\
\text { capable } \\
\text { of germinating }\end{array}$} & \multirow{2}{*}{$\begin{array}{c}\begin{array}{c}\text { Average } \\
\text { number of } \\
\text { blighted } \\
\text { leaves on } \\
20 \text { branches }\end{array} \\
\text { Sept. } 4\end{array}$} \\
\hline & & Feb. 20 & Apr. 30 & \\
\hline & amount & & & \\
\hline $37 \%$ sodium pentachlorophenoxide (SPP). & $8.0 \mathrm{lbs}$ & 0 & 0 & 30.5 \\
\hline $10 \%$ N-phenylmercuriethylenediamine (PMED). & $2.5 \mathrm{lbs}$ & 2 & 1 & 28.0 \\
\hline 75\% dinitro-ortho-secamylphenol (DNAP) ........ & $30.0 \mathrm{oz}$ & 79 & 26 & 172.5 \\
\hline $55 \%$ 2-sec-butyl-5, 6-dinitrophenol (DNBP).. & $43.5 \mathrm{oz}$ & 19 & 0 & 162.0 \\
\hline 1:4 mixture of $10 \%$ DNAP and $50 \%$ DNBP.. & $40.0 \mathrm{oz}$ & 9 & 11 & 150.3 \\
\hline 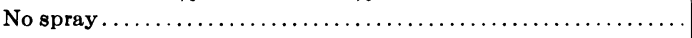 & $\ldots \ldots$ & 85 & 94 & 214.0 \\
\hline $\operatorname{LSD} 5 \%$ & & & & 87.3 \\
\hline LSD $1 \% \ldots \ldots$ & & & & 121.2 \\
\hline
\end{tabular}

mixture was low 60 days after the sprays were applied, only a moderate decrease in new infection occurred in the sprayed trees, an outcome for which we have no adequate explanation.

\section{SUMMARY AND CONCLUSIONS}

A disease of the almond, hitherto undescribed, was discovered in the Sacramento and San Joaquin valleys of California in 1950. This disease, which has been named leaf blight, is characterized by sudden withering and dying of leaves in summer. The affected leaf does not fall but remains on the twig where remnants of the petioles can be found the following spring.

No sign of a causal organism is evident on infected petioles until late fall or early winter when small black fruiting bodies of a fungus develop over the base of the petiole. Isolations proved that this fungus is present in most of the leaf petioles shortly after they die in summer. Upon inoculation of almond foliage the fungus produced typical symptoms of leaf blight.

In culture the fungus produced conidia most commonly on a thin but compact layer of hyphae. In the same culture, however, pycnidium-like 
structures often developed. These possessed a well-defined pseudoparenchymatous peridium but no ostiole in the specimens examined. On the host, conidia similar in size and shape were produced in structures which varied from acervulus-like to pycnidium-like. The former possessed neither a welldefined peridium nor an ostiole, the latter possessed both peridium and ostiole.

The leaf blight fungus resembles Hendersonia rubi Sacc., both with respect to the variability in its conidial fructifications and to the size, shape, and color of its conidia. Although Grove has transferred $H$. rubi to the new genus Coryneopsis we prefer to identify the leaf blight fungus as Hendersonia rubi Sacc. Reasons are given for doing so.

The optimum temperature for growth of the fungus was between $24^{\circ}$ and $30^{\circ} \mathrm{C}$. This was also the range most favorable for production and germination of conidia.

The leaf blight fungus survives in remnants of blighted petioles which hang on the tree where, in winter, it produces abundant conidia which apparently are responsible for all new leaf infections during the following summer. In late summer and early fall, buds in the axils of some of the affected leaves are killed by extension of the fungus from the petiole into the base of the bud. In spring, emerging flowers in the axils of other infected leaves are killed in a similar way.

According to the results of spraying experiments, leaf blight can be controlled either by the application of protective fungicides to the leaves in spring or by the application of eradicative sprays in late winter. Fungicides containing captan, dichlone, or ziram applied at the petal-fall stage or shortly thereafter gave adequate protection to the leaves, while those containing zineb and maneb were less effective. Proprietary formulations of sodium pentachlorophenoxide and $\mathrm{N}$-phenylmercuriethylenediamine applied to the dormant trees in late winter destroyed a large amount of the conidial inoculum and resulted in considerably less new infection the following summer. 


\section{LITERATURE CITED}

ARCHER, W. ANDREW

1926. Morphological characters of some Sphaeropsidales in culture. Annales Mycologici $24: 1-84$.

Grove, W. B.

1932. New or noteworthy fungi. XII. Jour. Bot. 70:33-38.

KidD, M. N., and A. BeAumont

1923-24. Apple rot fungi in storage. Brit. Mycol. Soc. Trans. 10:98-118.

SACCARDO, P. A.

1884. Sylloge fungorum $3: 424$.

WILson, E. E.

1943. Tests of eradicant sprays for use against Sclerotinia laxa and Coryneum beijerinckii in apricots and almonds. Phytopathology 33:506-16.

Wilson, E. E., and J. M. OGAWA

1956. New materials as eradicant fungicides. (Abst.) Phytopathology 46:31.

ZELLER, S. M.

1925. Coryneum ruborum Oud. and its ascogenous stage. Mycologia 17:33-41.

1927. A correction. Mycologia 19:150-51. 
The journal Hilgardia is published at irregular intervals, in volumes of about 600 pages. The number of issues per volume varies.

Subscriptions are not sold. The periodical is sent as published only to libraries, or to institutions in foreign countries having publications to offer in exchange.

You may obtain a single copy of any issue free, as long as the supply lasts; please request by volume and issue number from:

$$
\begin{aligned}
& \text { Agricultural Publications } \\
& \text { Room 22, Giannini Hall } \\
& \text { University of California } \\
& \text { Berkeley 4, California }
\end{aligned}
$$

The limit to nonresidents of California is 10 separate issues on a single order. A list of the issues still available will be sent on request.

In our publications it is sometimes convenient to use trade names of products or equipment rather than scientific identifications. In so doing it is unavoidable in some cases that similar products which are on the market under other trade names may not be cited. No endorsement of named products is intended nor is criticism implied of similar products which are not mentioned. 